\title{
Multi-drug resistance profile of extended spectrum $\beta$-Lactamases producing Escherichia coli isolated from sheep in Mosul city
}

\author{
F.R. Mahmood ${ }^{\circ}$ and I.M. Ahmed \\ Department of Microbiology, College of Veterinary Medicine, University of Mosul, Mosul, Iraq
}

\begin{tabular}{l} 
Article information \\
\hline Article history: \\
Received June 10, 2021 \\
Accepted June 30, 2021 \\
Available online November 27, 2021 \\
\hline Keywords: \\
Multi-drug resistance (MDR) \\
ESBL \\
Escherichia coli \\
Antibiotic resistance \\
\\
\hline Correspondence: \\
I.M. Ahmed \\
ihsanahmad1@ yahoo.com
\end{tabular}

\begin{abstract}
Multi-drug resistance (MDR) Escherichia coli have become a major threat due to their ability to overcome different types of antibiotics. However, Extended Spectrum $\beta$ lactamase E. coli (ESBLE) imposes an additional threat due to their ability to resist the $3^{\text {rd }}$ generation cephalosporins. Accordingly, our study aimed to investigate the antibiogram profile of ESBLE isolates obtained from sheep. A Total of 40 ESBLE isolates were included in this study which represents sheep fecal and milk samples. Twelve antibiotics were selected to perform antibiotic sensitivity tests following standard microbiological methods. The results of the study showed that the highest resistance percentages were recorded for tetracycline $97.5 \%$, ciprofloxacin $80 \%$, trimethoprim/sulfamethoxazole $65 \%$, and streptomycin $57.5 \%$. While other antibiotics recorded lesser values. On the other hand, all isolates were susceptible to gentamycin and tobramycin each at $92.5 \%$, followed by chloramphenicol and levofloxacin each at $82.5 \%$ and nitrofurantoin $72.5 \%$. While fewer values of sensitivity were recorded for streptomycin, trimethoprim /sulfamethoxazole, azithromycin, nalidixic acid, ciprofloxacin and, tetracycline. The study concluded that ESBLE of sheep origin that have additional resistance features to other antibiotics could be a major threat for spreading resistance and contaminating the environment and finally impose negative impact for response to antibiotic treatment in humans.
\end{abstract}

DOI: 10.33899/ijvs.2021.130475.1829, ๑Authors, 2021, College of Veterinary Medicine, University of Mosul.

This is an open access article under the CC BY 4.0 license (http://creativecommons.org/licenses/by/4.0/).

\section{Introduction}

Escherichia coli is one of the most important Enterobacteriaceae members that is capable of causing a variety of clinical infections in different species of animals and also humans $(1,2)$. During the last decade, the scene was become more complicated due to the involvement of extended-spectrum ß-lactamases (ESBLs) type E. coli in many animals infections including man $(3,4)$. Recently, the presence of such type of bacterial resistance has been reported in Iraq, in poultry (5), bovine milk (6), and feces of shepherd $\operatorname{dogs}(7)$. Furthermore, in a recent study on sheep, we were successfully able to isolate ESBL $E$. coli (ESBLE) from milk and feces of both diseased and healthy ewes in addition to the feces of their lambs (data submitted for publication). Such a wide distribution arise an important question about the possibility of circulating of such resistant bacteria between animals, the environment, and humans, and this challenging the legislation that has been regulated by the international organizations such as WHO, FAO, and OIE in terms of One Health concept to mitigate the effect of antibiotic resistance $(8,9)$. On the other hand, the presence of multidrug resistance $E$. coli has been reported worldwide which includes resistance to different groups of antibiotics such as aminoglycosides, fluoroquinolones, phenicols, macrolides, trimethoprim /sulfonamides, tetracyclines, nitrofuran derivatives, and carbapenems $(4,10)$. Such type of resistance surely increases the concern about successive treatment failure of current antibiotics and compels the drug companies to find 
Iraqi Journal of Veterinary Sciences, Vol. 35, Supplement II, 2021 (37-40)

Proceedings of the 3rd National (1 st International) Conference of Biology, College of Education for Pure Science, University of Mosul

other solutions to overcome this obstacle $(4,11)$. In Iraq, as one of the developing countries, the arbitrary and misuse of different types of antibiotics beyond the therapeutic and recommended doses in both human and veterinary sectors has complicated the problem, especially in the absence of clear and strict regulations that limited the use of antibiotics. Nevertheless, sheep rising in Iraq, as the main livestock trading, has a big share of such antibiotic misuse (12). Therefore, we believe that sheep that shedding ESBLE that could have additional features of resistance to other antibiotics might exaggerate the problem and accelerate the resistance range to the extent that develops multidrug resistance bacteria $(10,13)$. Accordingly, our study aimed to investigate the antibiogram pattern of ESBLE that have been isolated from sheep.

\section{Materials and methods}

\section{Bacterial isolates}

In this study, 40 positive ESBLE isolates were selected to perform an antibiotic susceptibility test. The obtained isolates were recovered from our previous study targeting detection of ESBLE from sheep in Mosul city. The details of ESBLE are listed in (Table 1). These isolates were previously confirmed for their ability to produce $\beta$ lactamases by culture on MacConkey agar plus cefotaxime, as third-generation cephalosporin according to Ahmed (6). Also, these isolates were tested by polymerase chain reaction (PCR) and confirmed positive for their ability to produce at least one of the resistance genes including CTX$\mathrm{M}, \mathrm{SHV}$, and TEM genes (data submitted for publication).

Table 1: Number of ESBLE isolates used in the study

\begin{tabular}{lc}
\hline Sample type & Tested sample (n) \\
\hline Milk (clinically healthy ewes) & 7 \\
Feces (clinically healthy ewes) & 13 \\
Feces (clinically healthy lambs) & 12 \\
Milk (ewes with clinical mastitis) & 4 \\
Feces (ewes with clinical mastitis) & 4 \\
\hline Total & 40 \\
\hline
\end{tabular}

\section{Antibiotic susceptibility test}

Antibiotic susceptibility test was performed according to Kirby-Bauer disc diffusion method following Clinical and Laboratory Standards Institute (CLSI) (14). The antibiotic discs (Bioanalyse/ Turkey) used in this study include, gentamycin $10 \mu \mathrm{g}$, streptomycin $25 \mu \mathrm{g}$, tobramycin $10 \mu \mathrm{g}$, nalidixic acid $30 \mu \mathrm{g}$, ciprofloxacin $10 \mu \mathrm{g}$, levofloxacin $5 \mu \mathrm{g}$, chloramphenicol $10 \mu \mathrm{g}$, azithromycin 15 $\mu \mathrm{g}, \quad$ trimethoprim/sulfamethoxazole $1.25 / 23.75 \mu \mathrm{g}$, tetracycline $10 \mu \mathrm{g}$, nitrofurantoin $100 \mu \mathrm{g}$, imipenem $10 \mu \mathrm{g}$. Briefly, bacterial suspension (equivalent to $0.5 \mathrm{McF}$ arland opacity standard) was prepared for each isolate and inoculated on Mueller-Hinton agar plates using a sterile swab. Then, the discs were placed on plates and incubated at $37^{\circ} \mathrm{C}$ for $24 \mathrm{~h}$. The zone of inhibition of each disc was measured using a digital caliper (Ingco, China). The results were interpreted by comparing inhibition zone diameters according to manufacturer instructions.

\section{Results}

The antimicrobial resistance pattern of the ESBLE showed an alarmingly high resistance to tetracycline $97.5 \%$, ciprofloxacin $80 \%$, trimethoprim/sulfamethoxazole $65 \%$, and streptomycin $57.5 \%$ followed by azithromycin $52.5 \%$. While nitrofurantoin, nalidixic acid, chloramphenicol, levofloxacin, and gentamycin recorded fewer values. On the other hand, all isolates were susceptible to gentamycin and tobramycin each at $92.5 \%$, followed by chloramphenicol and levofloxacin each at $82.5 \%$ and nitrofurantoin $72.5 \%$. While fewer rates of sensitivity were recorded for streptomycin, trimethoprim /sulfamethoxazole, azithromycin, nalidixic acid, ciprofloxacin, and tetracycline. Imipenem was the only drug that was $100 \%$ sensitive for all ESBLs producers (Table 2). Additionally, antibiotic resistance was different according to the source of samples, the feces and milk of ewes with clinical mastitis showed 4/4 (100\%) resistance for each streptomycin, ciprofloxacin, tetracycline, and trimethoprim/ sulfamethoxazole. While feces and milk of healthy ewes showed $13 / 13(100 \%)$ resistance to tetracycline and fewer values were recorded for other antibiotics.

Table 2: Antimicrobial resistance profiles among ESBLE isolates from sheep

\begin{tabular}{lccc}
\hline \multirow{2}{*}{ Antibiotic } & \multicolumn{3}{c}{ Number $(\%)$} \\
\cline { 2 - 4 } & Resistance & Intermediate & Sensitive \\
\hline Gentamycin & $3(7.5)$ & 0 & $37(92.5)$ \\
Streptomycin & $23(57.5)$ & 0 & $17(42.5)$ \\
Tobramycin & 0 & $3(7.5)$ & $37(92.5)$ \\
Nalidixic acid & $8(20)$ & $22(55)$ & $10(25)$ \\
Ciprofloxacin & $32(80)$ & 0 & $8(20)$ \\
Levofloxacin & $6(15)$ & $1(2.5)$ & $33(82.5)$ \\
Chloramphenicol & $7(17.5)$ & 0 & $33(82.5)$ \\
Azithromycin & $21(52.5)$ & $8(20)$ & $11(27.5)$ \\
SXT & $26(65)$ & 0 & $14(35)$ \\
Tetracycline & $39(97.5)$ & 0 & $1(2.5)$ \\
Nitrofurantoin & $11(27.5)$ & 0 & $29(72.5)$ \\
Imipenem & 0 & 0 & $40(100)$ \\
\hline
\end{tabular}

\section{Discussion}

Human and veterinary medicine share many critical classes of antibiotics especially the $3^{\text {rd }}$ and $4^{\text {th }}$ generation cephalosporins (10). However, the arbitrary prescription and misuse of antibiotics even as prophylactic or as growth promoters have complicated the problem of antibiotic resistance which emerged new strains of bacteria that have 
Iraqi Journal of Veterinary Sciences, Vol. 35, Supplement II, 2021 (37-40)

Proceedings of the 3rd National (1st International) Conference of Biology, College of Education for Pure Science, University of Mosul

been listed under MDR (13-16). E. coli is one of the most important commensals in both humans and animals with worldwide distribution $(17,18)$. Nevertheless, the emerging of this bacterium as the main contributor of ESBL leads to the transmission of resistance to other bacterial species $(1,17)$. Furthermore, resistance to other antibiotic classes means that we are facing a new problem that has a negative impact on human public health due to the substitution of sensitive normal flora with those with MDR properties $(19,20)$. Our result showed that tetracycline, trimethoprim/ sulfamethoxazole, and streptomycin were recorded the highest resistance among the tested antibiotics. This was expected because these broad-spectrum antibiotics are commonly used in veterinary clinics for the treatment of bacterial infections caused by both Gram-positive and Gram-negative bacteria. These results were in agreement with the recent study in Malaysia by Haulisah et al. (10) as they recorded complete or almost complete resistance 100\% against each amoxicillin and erythromycin, tetracycline $95.1 \%$ and more than $90 \%$ of isolates were not-susceptible to seven of nine tested antibiotics. Another recent study by Pehlivanoglu et al. (4) also reported that the highest resistance percentage of $E$. coli was found against tetracycline and streptomycin $52.9 \%$ from dairy cattle and sheep farms in Burdur, Turkey. While Batabyal et al. (21) found that amoxicillin/clavulanic acid $83.3 \%$, tetracycline $75 \%$, and gentamycin $58.3 \%$ were the most antibiotic resistant ESBLE from milk samples collected from healthy cows in different parts of West Bengal, India. Feces of healthy ewes and lambs showed high resistance to tetracycline and ciprofloxacin and this could explain the possibility of transmission of resistance from ewes to lambs and may also contribute to disseminate resistance to the environment. This was in agreement with previous studies $(4,12)$. It is clear that ESBLE keeps developing its antibiotics resistance ability and generates a new type of MDR bacteria that have a wide range of resistance to various antibiotics.

\section{Conclusion}

The involvement of MDR type of ESBLE in sheep feces and milk could impose an additional burden and left few choices to win the battle against antibiotic resistance.

\section{Acknowledgments}

The authors would like to thank the University of Mosul, College of Veterinary Medicine for supporting our research, which has helped to enhance the quality of this work.

\section{Conflict of interest}

The authors declare that they have no conflict of interest.

\section{References}

1. Alegria A, Arias-Temprano M, Fernández-Natal I, Rodriguez-Calleja JM, Garcia-Lopez M-L, Santos JA. Molecular diversity of ESBLproducing Escherichia coli from foods of animal origin and human patients. Int J Environ Res Public Health. 2020;17:1312. DOI: 10.3390\%2Fijerph17041312

2. Royden A, Ormandy E, Pinchbeck G, Pascoe B, Hitchings MD, Sheppard SK, Williams NJ. Prevalence of faecal carriage of extendedspectrum $\beta$-lactamase (ESBL)-producing Escherichia coli in veterinary hospital staff and students. Vet Rec Open. 2019; 6(1):e000307. DOI: $10.1136 /$ vetreco-2018-000307

3. Pishtiwan AH, Khadija KM. Prevalence of blaTEM, blaSHV, and blaCTX-M genes among ESBL-producing Klebsiella pneumoniae and Escherichia coli Isolated from thalassemia patients in Erbil, Iraq. Mediterr J Hematol Infect Dis. 2019;11(1):e2019041. DOI: 10.4084/mjhid.2019.041

4. Pehlivanoglu F, Ozturk D, Turutoglu H. Carriage of plasmidic AmpC Beta-Lactamase producing Escherichia coli in cattle and sheep and characterisation of the isolates in terms of antibiogram profiles, phylogeny and virulence. Kafkas Univ Vet Fak Derg. 2020;26(4):469476. DOI: $10.2010 .9775 / \mathrm{kvfd} .2019 .23541$

5. Al-Sharook M, Hassan A. Isolation and identification of extendedspectrum beta-lactamase (ESBL)-producing Escherichia coli from broiler in Erbil, Iraq. Iraqi J Vet Sci. 2017;31:31-38. DOI: 10.33899/ijvs.2017.126717

6. Ahmed IM. Detection of CTX-M gene in extended spectrum $\beta$ lactamases producing Enterobacteriaceae isolated from bovine milk. $\begin{array}{lllll}\text { Iraqi J Vet } & \text { Sci. }\end{array}$ 10.33899/ijvs.2020.126909.1412

7. Ahmed IM, Aldabbagh SY, Jwher DM. Molecular characterization of extended spectrum cephalosporin resistant Escherichia coli isolated from dogs. Iraq. Iraqi J Vet Sci. 2021;35(3):473-478. DOI: 10.33899/ijvs.2020.127032.1441

8. Rousham EK, Unicomb L, Islam MA. Human, animal and environmental contributors to antibiotic resistance in low-resource settings: integrating behavioural, epidemiological and One Health approaches. Proceedings of the Royal Society B: Biol. Sci. 2018;285:20180332. DOI: 10.1098/rspb.2018.0332

9. Urumova V. Extended spectrum beta lactamase producing animal enterobacteriaceae isolates as potential risk to public health-review. Rev Med Vet. 2015;166:192-207. DOI: 10.21203/rs.2.24496/v1

10. Haulisah NA, Hassan L, Bejo SK, Jajere SM, Ahmad NI. High levels of antibiotic resistance in isolates from diseased livestock. Front. vet. sci. 2021;8:300. DOI: 10.3389/fvets.2021.652351

11. Kozak GK, Boerlin P, Janecko N, Reid-Smith RJ, Jardine C. Antimicrobial resistance in Escherichia coli isolates from swine and wild small mammals in the proximity of swine farms and in natural environments in Ontario, Canada. Appl Environ Microbiol. 2009;75:559-566. DOI: $10.1128 / \mathrm{aem} .01821-08$

12. Almashhadany DA. Monitoring of antibiotic residues among sheep meat in Erbil city and thermal processing effect on their remnants. Iraqi J Vet Sci. 2020;34:217-222. DOI: 10.33899/ijvs.2019.125814.1161

13. Tamma PD, Doi Y, Bonomo RA, Johnson JK, Simner PJ, Arlgtpdyb RA. A primer on AmpC $\beta$-lactamases: necessary knowledge for an increasingly multidrug-resistant world. Clin Infect Dis. 2019;69:14461455. DOI: $10.1093 / \mathrm{cid} / \mathrm{ciz} 173$

14. Clinical, Institute LS. Performance standards for antimicrobial susceptibility testing. New York: Clinical and Laboratory Standards Institute Wayne; 2017. [available at]

15. Filioussis G, Kachrimanidou M, Christodoulopoulos G, Kyritsi M, Hadjichristodoulou C, Adamopoulou M, Tzivara A, Kritas SK, Grinberg A. Bovine mastitis caused by a multidrug-resistant, mcr-1positive (colistin-resistant), extended-spectrum $\beta$-lactamaseproducing Escherichia coli clone on a Greek dairy farm. J Dairy Sci. 2020;103:852-857. DOI: $10.3168 /$ jds.2019-17320

16. Palmeira JD, Ferreira HN. Extended-spectrum beta-lactamase (ESBL)-producing Enterobacteriaceae in cattle production-a threat 
Iraqi Journal of Veterinary Sciences, Vol. 35, Supplement II, 2021 (37-40)

Proceedings of the 3rd National (1st International) Conference of Biology,

College of Education for Pure Science, University of Mosul

around the world. Heliyon. 2020;6:e03206. DOI: 10.1016/j.heliyon.2020.e03206

17. Bajaj P, Singh NS, Virdi JS. Escherichia coli $\beta$-lactamases: what really matters. Front Microbiol. 2016;7:417. DOI: 10.1016/j.heliyon.2020.e03206

18. Torres AG, Arenas-Hernandez MM, Martínez-Laguna Y. Overview of Escherichia coli. Pathogenic Escherichia coli, Latin America. 2010:17.

19. Lee S, Mir RA, Park SH, Kim D, Kim H-Y, Boughton RK, Morris Jr JG, Jeong KC. Prevalence of extended-spectrum $\beta$-lactamases in the local farm environment and livestock: challenges to mitigate antimicrobial resistance. Crit Rev Microbiol. 2020:1-14. DOI: 10.1080/1040841X.2020.1715339

20. Bitrus AA, Mshelia PA, Kwoji ID, Goni MD, Jajere SM. Extendedspectrum beta-lactamase and ampicillin Class C beta-lactamaseproducing Escherichia coli from food animals: A review. Int J One Health. 2019;5:65-75. DOI: 10.14202/IJOH.2019.65-75

21. Batabyal K, Banerjee A, Pal S, Dey S, Joardar SN, Samanta I, Isore DP, Singh AD. Detection, characterization, and antibiogram of extended-spectrum beta-lactamase Escherichia coli isolated from bovine milk samples in West Bengal, India. Vet World. 2018;11:1423. DOI: $10.14202 \% 2$ Fvetworld.2018.1423-1427

\section{صورة المقاومة المتعددة للأدوية لجراثيم

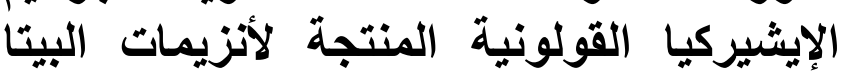

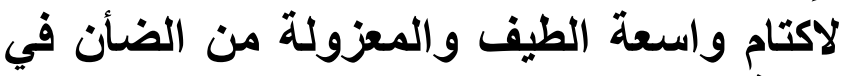 مدينة الموصل}

فاطمة رافع محمود و إحسان منير احمد

فرع الأحياء المجهرية، كلية الطب البيطري، جامعة الموصل، المبل،

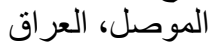

الخلاصة

تعتبر الإيشريكيا القولونية ذات صفة المقاومة المتعددة للأدوية

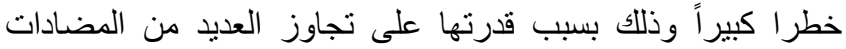

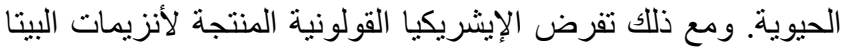

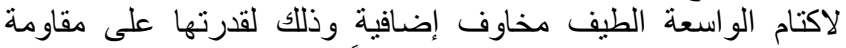

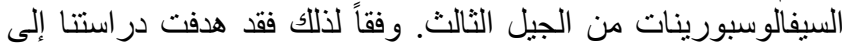
التحري عن صفة المقاومة للمضادات الحيوية لجراثيم الإيثريكيا

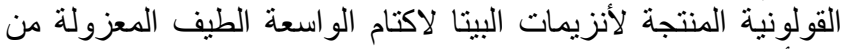

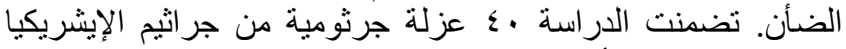

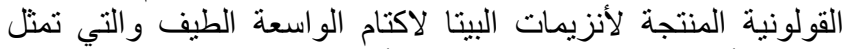

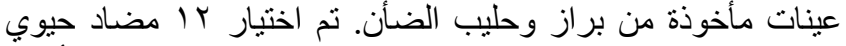
لإجر اء فحص الحساسية للمضادات الحيوية باستخدام طرق الحن الأحياء المجهرية القياسية. أظهرت الاراسة أن اعلى نسبة مقاومة كانت

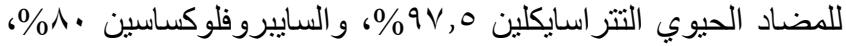

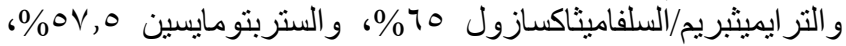

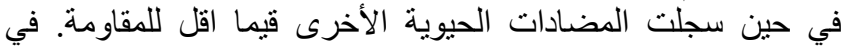

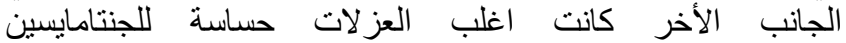

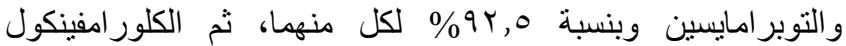

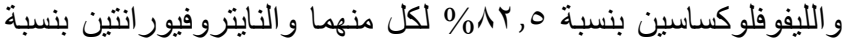

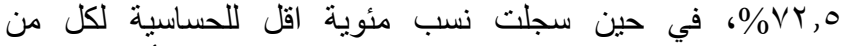

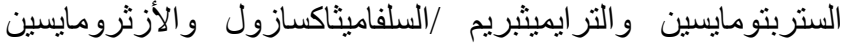

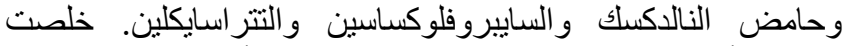

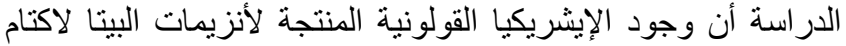

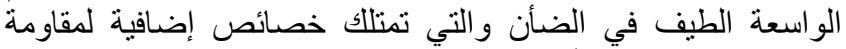

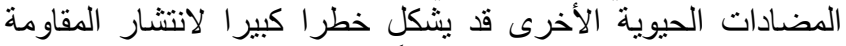
وتلوث البيئة وبالتالي قد ينعكس سلباً على الاستجابة للعلاج باستخدام المضادات الحيوية في الإنسان. 